\title{
Union Campaigns in Germany directed against Inequality: The Minimum Wage Campaign and the Emmely Campaign
}

\author{
Jörg Nowak, University of Kassel, Germany
}

\begin{abstract}
The article analyses two campaigns in Germany in the context of trade unions that deal with inequality. The minimum wage campaign successfully led to the implementation of a legal minimum wage in Germany. The Emmely campaign reinstated a supermarket cashier who was sacked after a strike, and the federal labour court introduced a slight change of labour law in the wake of the campaign. Both campaigns relied on overwhelming support from the general population.
\end{abstract}

\section{Introduction}

In this article I introduce two campaigns led by German trade unions against increasing inequality. The first is the minimum wage campaign which started in 2006 and ended on 3 July 2014 with Parliament's implementation of the minimum wage. The second campaign is the so-called 'Emmely campaign' in which unions and social movements rallied around a supermarket cashier who was sacked in January 2008 after thirty-one years of service for the alleged theft of deposit cheques with a value of 1,30 Euro. The campaign ran for more than two years, until the federal labour court reinstated the cashier on 10 June 2010.

The two campaigns were very different. One was led from the top level of the umbrella organisation of trade unions, the Deutscher Gewerkschaftsbund (DGB, German Coalition of Trade Unions). The second was led by a small group that was partly composed of trade union members but that had little union support and had to be organised outside of and against the local union branch.

The campaign for a legal minimum wage was led by the union leadership after certain sections of rank-and-file unionists and union officials from different levels exerted pressure on the leadership to do something about the issue. Germany was one of the few developed countries with no general minimum wage, which made possible very low wages at the bottom end. The second campaign was effectively led by a small solidarity committee of about ten persons with very limited funds. In the course of the campaign the leadership of the service union Verdi got involved in certain aspects, although its local branch abstained from any support for the cashier even though she had been a union member for many years.

Both campaigns were possible because they enjoyed the overwhelming support of the public. About $60 \%$ of the population thought the sacking of Emmely, the cashier, was unjust, and $70-80 \%$ in different polls voiced their support for a minimum wage in Germany.

\section{DGB's Minimum Wage Campaign}

The campaign emerged out of a joint discussion in 2001 of the Party for Democratic Socialism (PDS) ${ }^{1}$ with the trade union for Food, Restaurants and Tourism (Nabrung, Genuß und Gaststätten, NGG) which has about 200000 members (Linksfraktion, 2013). The NGG had already taken a decision in 1999 to demand a legal minimum wage, but with almost no public support. The 
members of this trade union were and are affected by low wages to a larger extent than other unions. It was the PDS that facilitated a large public presence in the demand for a minimum wage in the years before 2005. During the 2002 federal conference of the DGB, Verdi and the NGG put forward the demand for a minimum wage, but the conference delegates did not approve it. ${ }^{2}$

In 2002 the PDS introduced a bill for a minimum wage in the German Parliament, which all other parties in Parliament rejected. The demand was identified with this party until 2006 as it was one of its central demands. The Social Democratic Party (SPD) rejected the demand in 2005 with the argument that a legal minimum wage would be in conflict with the principle of the autonomy of collective negotiations between employers and trade unions from any government intervention. In 2005, the demand gained more weight as the leader of one of the big trade unions in the DGB rallied behind it: Frank Bsirske, head of the service union Verdi, raised the demand and the PDS (which had started to transform into the Left Party at that time) put the demand for a minimum wage at the centre of its campaign for the 2005 national elections. The fact that Verdi adopted the demand for a minimum wage was a crucial change since it moved the demand to the centre of the trade union movement - the two trade unions Verdi and IG Metall are the most important ones due to their large membership.

The minimum wage campaign started with a resolution at the DGB's 2006 congress, and was effectively introduced to the public in 2007. An intense public campaign was started in January 2008 with propaganda posters, the distribution of information in city centres and the launching of the website www.mindestlohn.de that documents the campaign. The DGB organised rallies and public meetings in favour of the minimum wage, but the main arena for the campaign has been its continual presence in mass media such as television, newspapers and the Internet.

The first demand was a general mininum wage of 7,50 Euro. The campaign was an object of debate in the DGB, because IG Metall feared that the demand for a legal minmum wage could be used to lower wages that are above the minimum wage.

The main reason for the minimum wage campaign was the fact that the low-wage sector in Germany had expanded rapidly since the 1990s. In 2007, 4.6 million workers out of a total work force of 40 million people earned a wage below 7,50 Euro an hour. In December 2013, five million workers were earning below the new minimum wage demand of 8,50 Euro an hour. The peak was around 2010, when 16\% of all workers earned below 8,50 Euro. The number dropped to 10\% in December 2013, due to minimum wages in single sectors.

There are strong regional and sectoral disparities in the distribution of these low-wage jobs. While in West Germany only 6\% worked below 8,50 Euro in December 2013, it was 27\% in East Germany (Bispinck/WSI-Tarifarchiv, 2014). Left out of these calculations are about one million self-employed workers who earn below minimum wage.

In 2008 , surveys showed a support of $81 \%$ for a legal mininum wage. ${ }^{3}$ In the course of the debate, public support gained momentum, peaking in 2013 at $85 \%$. Due to inflation, the actual minimum wage demand of the DGB was raised to 8,50 Euro in May 2010, which was confirmed at the trade union congress in May 2014.

Most European countries have had a legal minimum wage for a number of years. Even if it is not always possible for workers to enforce legal action against wages below the minimum wage, the legal minimum wage is a kind of benchmark. In Germany, about $53 \%$ of the workforce in West Germany and 36\% in East Germany were covered by collective agreements in 2012. ${ }^{4}$ Some of these collective agreements did not reach sufficient wages due to the weakness of the trade unions, especially in East Germany. Because some wages that were agreed upon in collective negotiations between trade unions and employers in East Germany were below 4 Euro in 2007 (hairdressers only got 3,82 Euro per hour), the mininum wage campaign in Germany addressed important problems for the German working class. In late 2013, employers who paid wages of 1,54 Euro per hour to 
pizza delivery drivers in the East German state of Brandenburg, and 2,84 Euro for work in a call center in the Ruhr area were sued (WAZ, 2009; Die Welt, 2014).

In order to compare minimum wages in other European countries with the demand of the DGB, I will give a brief overview: The minimum wage in the United Kingdom, introduced in 1999, was $f, 6,31$ in 2013, which equals 7,35 Euro. In France, a minimum wage was introduced in 1950, and its level in 2014 was about 9,43 Euro. The mininum wage in Spain was introduced in 1963, and was about 21,38 Euro per day in 2014.

The main goal of the DGB's minimum wage campaign - a legal mininum wage - was reached after the elections in 2013. The trade unions pressurised the SPD to make a minimum wage one of the central issues of government. Previous governments had reacted to the overwhelming support of the population for a minimum wage and introduced mininum wages for certain sectors of the economy. Twelve sectors were covered by a minimum wage before the introduction of the general minimum wage on 1 January 2015, ranging from security guards and janitors in East Germany with 7,50 Euro to construction workers in West Germany with 13,70 Euro. As a result, in 2010, four million workers were protected by minimum wages.

The minimum wage is only valid for a whole sector if certain criteria are met. These are the same criteria that are applied in order to decide if a collective negotiation is valid for a whole sector. The main criterion is a quorum: 50\% of all companies in the sector have to join the collective negotiation. However, it is under dispute if this $50 \%$ refers to the number of employees or to the number of companies. A massive exit of companies from the asssociation of employers makes it harder and harder to meet this criterion, especially in the area of retail services. A minimum wage in the retail sector failed because of recent developments, among them an exit of employers from the corporate system of negotiations. Retail sector employers say they want to agree on a minimum wage between 7,20 to 7,78 Euro, but they claim that they want to introduce it via a new system of collective negotiations that would not include the manifold rules included in the present system. Finally, these sectoral negotiations have been stopped due to the introduction of a general minimum wage. But these difficulties in the retail sector disclose why intervention of the government was important for the trade unions.

\section{Responses of political parties}

The demand for a legal minimum wage came from the PDS/Left Party, which is one of the smaller German parties, with $11.9 \%$ of the votes in the 2009 elections for the national Parliament, and $8.6 \%$ of votes in the 2013 elections.

The next party to take up the demand was the SPD in July 2006, a few months after the campaign started in April that year. Later that same year, the Green Party followed suit. The conservative party of the Christian Democrats (CDU) adopted the demand but changed the concept from 'minmum wage' (Mindestlohn) to 'lowest possible margin for wages' (Lohnuntergrenze) in its party convention in November 2011. The project did not just have a new name; it also had some different features: The CDU proposed that, while a mininum wage would be based on national legislation and establish a unified minimum wage, it planned to restrict this project to areas which were not affected by collective agreements. For these areas, employers and trade unions should, they said, negotiate on a minimal margin, but with specific minimums differing across sectors and geographical regions.

The strongest resistance to legal regulation came from the Free Democratic Party (FDP), which has a liberal stance with regard to economic issues, civil liberties and moral values. The FDP emphasised that many jobs would cease to exist if a minimum wage or something similar were decided upon. 


\section{Legal general minimum wage in 2015}

In the 2013 campaign for federal elections in Germany, the minimum wage was highlighted by the SPD candidate, Mr. Steinbrück; the demand became one of the central issues during the negotiations for a coalition government between CDU/CSU and SPD. The government programme finally included a plan to introduce a general minimum wage in Germany of 8,50 Euro by 2017. Employees who are not covered by collective agreements will receive the minimum wage from 1 January 2015, and all other employees who earn less have to wait until 2017. It has been noted that this minimum wage does not succeed in securing a pension covering minimum expenses after retirement.

Soon after the government started work in mid-December 2013, a debate about possible exceptions to the minimum wage was begun by CDU politicians. They demanded that the minimum wage should not be applied to retired people, students, seasonal workers, taxi drivers and youth. A scientific study published in January 2014 showed that these exceptions would affect $40 \%$ of the five million workers who earn below 8,50 Euro (Amlinger, Bispinck and Schulten, 2014). In fact, the government programme contains a paragraph about exceptions from the minimum wage which is quite vague.

The law that was passed in the German federal Parliament on 3 July 2014 in order to introduce a minimum wage is a compromise solution between the CDU and the SPD. There will be no delay regarding the introduction of the minimum wage; the date of effective introduction was moved to 1 January 2015. On the other hand, a number of exceptions have been agreed upon: Young people under 18 do not get a minimum wage, and unemployed persons who have been unemployed for more than two years can be hired at below minimum wage for the first six months of employment. Sectors that are covered by collective negotiations below minimum wage will enter the minimum wage later than 2015, and newspaper deliverers will also enter the minimum wage only in 2017. They can be paid 25\% less than minimum wage in the first year and 15\% less in the second year. Seasonal workers can be employed below minimum wage for seventy days a year, and employers can integrate costs for food and housing into the minimum wage calculation (Der Spiegel, 2014a). These exceptions were vehemently opposed by both the SPD and the DGB, but due to pressure from the CDU, the SPD agreed to the exceptions. It is estimated that about one million unemployed are theoretically affected by the above exception. In addition, 60000 prison inmates and 300000 disabled people in special workshops are working for an hourly wage below 2 Euro an hour. The Green Party and the Left Party mobilised to include disabled people in workshops into the minimum wage, but the SPD and the CDU refused to take up this demand.

The introduction of the minimum wage will raise the wages of about 3.7 million workers. It was met with an overwhelming support of $88 \%$ of the population. The minimum wage will save between 2.2 billion and 3 billion Euro of state expenditure, because state support for low-waged workers will decline (Der Spiegel, 2014b). The minimum wage cannot rise until 2017, and the new amount will be decided by a commission composed of employers and trade unions.

The official name of the law is Tarifautonomiestärkungsgesetz: The Green Party approved the law in Parliament, while the Left Party abstained from voting and expressed its demand for a minimum wage of 10 Euro an hour. Ingo Kramer, the president of the employer's organisation BDA, called the new minimum wage law a 'threatening intervention into collective negotiations' (FAZ, 2014: 1).

In a statement of social scientists who work for the trade union think tank WSI, it was emphasised that two aspects remained unclear in the new law: First, there are no regulations regarding whether payments for overtime or bonuses would be considered as extra or if they would be counted as contributing to the minimum wage payment (Schulten and Bispinck, 2014). Experience from other countries shows that a clear-cut solution - keeping the minimum wage and extra payments apart - contributes to a broader implementation of the minimum wage. Second, the 
new law is unclear about how the payment of the minimum wage will be monitored and controlled. Schulten and Bispinck (2014) estimate that an additional 2000 workers in the relevant institution will be necessary to facilitate effective control.

\section{Conclusion}

The minimum wage campaign reflects the new constellation of the labour market and left politics in Germany after the SPD turned to neo-liberalism in 2002 with the workfare programme Agenda 2010. After that time, the number of mini-jobs in which one can legally earn 400 Euro a month but without basic social security continued to rise.

The neo-liberal turn of the SPD led to a split of leftist unionists from the party. This splinter group, the Electoral Alternative for Social Justice (WASG), united with the East German PDS in 2005 to form the Left Party. This new constellation and the further extension of the low-wage sector in Germany forced the DGB to take a position. The DGB soon discovered that this situation opened up a huge opportunity to engage in a proper political debate as a trade union umbrella, which had not been the case for more than twenty years. This new-found strength also contributed to a new form of collaboration with the SPD after the relationship between the SPD and the DGB faced severe tensions when the former implemented its workfare programme between 2002 and 2004. That campaign was also an instrument to contain the influence of the Left Party in the DGB. The fact that the head of Verdi, the second most important trade union in Germany with 2.1 million members, campaigned for a minimum wage demand in 2005 while all other parties except the Left Party rejected it, rang the alarm bells in the still-dominant social-democratic networks inside of the DGB trade unions. The role of the minimum wage for the relationship between the DGB and the SPD is a paradoxical one. Since the SPD adopted the demand, and even more after it was able to integrate it into the government programme in 2013, the demand was a vehicle to improve the relationship between both actors. However, because the minimum wage law included many exceptions, the relationship between trade unions and the SPD got cooler again, at least in late June 2014 when the number of exceptions became public. Frank Bsirske, head of Verdi, protested vehemently against the exceptions, emphasising that they would affect the weakest members of the workforce. On 30 June 2014 Verdi called for a public demonstration close to the German Parliament, and on July 1 Verdi started an Internet petition that was sent to all its members via email in order to enhance pressure before the law was approved on 3 July 2014 (Verdi, 2014).

The fact that the new government coalition finally decided on a general legal minmum wage can be seen as a major success for both the trade unions and the SPD. It became an essential demand for the SPD to prove their stance towards the interests of the working class. Another important factor was that a majority of managers were also in favour of a minimum wage - about $57 \%$ according to a survey of the institute Forsa (Handelsblatt, 2013). It turned out that the managers saw a minimum wage of 8,88 Euro, which is above the demand presented by the DGB, as acceptable. Thus, as can be seen with the example of the retail sector, the association of employers presented a much harsher stance on the minimum wage than its members.

The implementation of minimum wages in specific sectors was a first success of the campaign because in some of these sectors wages were among the lowest that could be found in Germany. It was also a success that the trade unions could be convinced that a minimum wage does not interfere with the system of collective negotiations. In a study published in September 2013, Claudia Weinkopf and Gerhard Bosch from Duisburg University emphasise that there is no valid correlation between wages in collective agreements and minimum wages. Thus, the fear of trade unionists that mininum wages would contribute to weaken systems of collective negotiations seems to be overrated. Weinkopf and Bosch (2013) found that minimum wages contribute to set minimum standards for the lower end of the wage spectrum, while collective agreements enhance the equality 
of wages in the middle spectrum. The minimum wage campaign as a whole contributed to raise consciousness about the rapid extension of the low-wage sector in Germany and served to give popular sentiments about increasing inequality a voice in political discourse. The campaign also strengthened the efforts to integrate minimum wages into laws on public procurement.

In the eight years of the minimum wage campaign (2006-2014), the trade unions successfully opened a political discourse and gained support for their demand. The campaign first helped to establish basic conditions in some of the low-wage sectors, and eventually succeeded in achieving its main goal.

\section{The Emmely Campaign}

The Emmely campaign emerged out of a strike in the German retail sector. From 2007 to mid-2008, the service union Verdi, part of the DGB, led an eighteen-month strike in the retail services sector that went largely unnoticed by the public. The unions fought against wage cuts and campaigned for a $6 \%$ increase in wages in that sector, but the employers' association resisted a compromise due to the low unionisation in this sector and the successful use of temporary workers as strikebreakers. The temporary workers, of course, could not participate in the strike, because they were not covered by the collective agreement under dispute.

Due to the lack of effectiveness of the strike, the Berlin branch of Verdi started to experiment with new forms of action. Verdi collaborated with some small groups of the radical left as well as workers from a number of retail companies, and organised a blockade of a supermarket of the brand 'Reichelt' for one day in the summer of 2007. The picketers encouraged customers not to enter the supermarket. The action was quite successful in terms of a high loss of this particular supermarket for one day. Due to legal rules, the blockade had to leave a small alley where customers could pass if they wanted to enter the supermarket. This kind of action - mobilising in front of a supermarket and encouraging customers not to buy there - was soon banned by a local court after intervention from the Board of Directors of Reichelt, and the trade union retreated from repeating this kind of action (Arps, 2008).

Nonetheless, several retail workers contacted activists from the radical left, while one of the members of the radical left groups shot a documentary about the strike. One of those workers was 49-year-old Barbara Emme; Emmely was a nickname used by her friends and colleagues. She had organised the retail strike in her shop, and by December 2007 she was one of the last workers participating in the strike in this particular shop, after most of the other workers were intimidated by the shop's management.

In January 2008 Emmely was accused of stealing two deposit cheques of 1,30 Euro that a customer had lost in the supermarket. The theft was not proven and Emmely denied it. But due to a German law that allows employers to fire people on the suspicion of a mistake such as theft, she was fired in February 2008 after thirty-one years on the job. She had started to work in 1977 at the age of seventeen in the retail company $\mathrm{HO}$ in the socialist German Democratic Republic. HO was subsequently bought by the West German retail chain Kaiser's Tengelmann GmbH, and her contract was continued by the new company. Emmely was a single mother raising three children on her own. She was working near full-time for Kaiser's (32 hours per week), making around 1600 Euro per month. At that time the core workforce of Kaiser's was steadily shrinking; permanent workers were increasingly replaced by students and temporary workers, earning a lower hourly wage than the core workforce.

In Emmely's case two specificities in the German labour law were combined; they were a widespread phenomenon in German workplaces: dismissal by suspicion (Verdachtskündigung) and petty-stuff dismissal (Bagatellkündigung). Dismissal by suspicion means that you can be fired because 
your employer suggests you violated the work contract. The employer does not have to prove this suggestion; as the name of this regulation indicates, the suspicion is enough. The legal argument is that if the employer is suspicious that the worker violated the contract, this destroys the trust relationship between employer and employee. Suffice it to say that this regulation paves the way for arbritrary measures by employers. It was introduced during German fascism in 1938 and was kept by West German labour jurisdiction until now.

The second legal basis for the sacking of Emmely was the petty-stuff dismissal. This argues that a worker can be sacked for theft no matter how low the value of the items stolen, even if it was for less than one cent. This jurisdiction is still in use in Germany, too.

Both laws were frequently used to sack workers who were union organisers or shop stewards, or who were working too slowly, were too old or belonged to the core workforce with better contracts than newly hired temporary workers. The German trade unions accepted these laws because they did not see a way to oppose them. This attitude resulted from a pragmatic, not to say fatalistic, perspective of the trade unions to use their resources where they thought it would be effective and yield results.

Emmely consulted with a lawyer from her trade union, Verdi. The lawyer advised her not to go to the public but to negotiate a severance payment. This was the predominant way the trade unions had dealt with such matters in the last thirty years. But Emmely decided to fight for her right to stay in her workplace. She hired another lawyer who was motivated to take her case to court. The first date at the court was the beginning of the Emmely campaign. Because there was a huge debate about the surveillance of employees in other retail chains in spring 2008, the public was already sensitised to the issue. The Emmely solidarity committee started to organise rallies in front of Kaiser's supermarkets, inviting left-wing politicians from the Green Party and the Left Party to attend. In the first court case in August 2008 the sacking of Emmely was confirmed by the Berlin court, and the case was local news in some newspapers.

After the first court case, Emmely's local trade union branch called for a boycott campaign against her employer, demanding that she continue in the job. The Works Council (Betriebsrat) of Kaiser's in Berlin is a member in the same trade union, Verdi, but they felt offended by the call for a boycott and feared that it could damage the company and lead to layoffs and closures of shops. It was revealed later in an interview that Christel Laubisch, the head of the Betriebsrat, gave to the press, that she and her colleagues blackmailed the local branch of Verdi by indicating that the Betriebsrat would leave Verdi if the union did not stop the boycott campaign. This led the local union branch of Verdi to withdraw any support for Emmely in September 2008, urging her again to take a severance payment.

This difficult situation of the trade union is a result of the German legal structure which is anchored in the specific law on workers' representation. Germany has a two-tiered system of representation: The trade unions are responsible for collective negotiations, while the Works Council addresses worker grievances, working conditions and so on. The law lays emphasis on the Betriebsrat as an important institution which is protected on a legal basis, rather than the trade union which members of the Betriebsrat might or might not join. In this respect, the Betriebsrat is often more powerful than the trade union with respect to the power structure inside companies. In addition, the Betriebsrat sees itself very often as a co-management body that has to protect the company. In the case of Kaiser's, the composition of this body reinforced that situation: The workers' representatives in the Berlin district of Kaiser's, as in many other companies, are predominantly composed of employees who work in higher levels in the company and not by supermarket workers without any leadership tasks.

In spite of the trade union withdrawing its support, Emmely, the solidarity committee and her lawyer did not step back. They went to the court a second time, and the court case hearings were 
scheduled for January and February 2009. At this time, the debate about the bonuses of bankers was very vivid. One day before Emmely's first court hearing a chief manager of German Telekom got away with mild treatment in court, although he had cheated with funds amounting to several millions of euros. Both events fuelled the public's curiosity about a cashier being sacked for an alleged theft of 1,30 Euro.

Emmely also lost the second court case in February 2009, but this time the case was covered by television and all major newspapers in Germany. The German tabloid BILD put the case on the front page and even newspapers in South Korea and Nigeria reported it. Politicians from all political parties in Germany commented on the case and agreed that the treatment of Emmely was unfair. $\mathrm{Mr}$ Thierse, the president of the German Parliament, found harsh words for the court, which caused another debate on the topic. At that point, the federal board of Verdi stepped in and guaranteed financial support for a third court case which was to be held at the federal level. The case also sparked a debate among experts in labour jurisprudence in Germany.

After Emmely's second court case, a lot of similar cases started to be reported by newspapers, and the new-found interest in the topic helped to exert pressure on judges and employers. For example, one worker in the Ruhr area stole a fragment of one euro-cent - 0,00014 Euro - because he charged his mobile at his workplace and was fired for theft; however, he was able to stay in his job due to the storm of rage that erupted after the case became public (Simantke, 2010). In the meantime, the Emmely solidarity commitee not only coordinated the press work before and after the court cases, but also organised a number of public events all over Germany, including the participation of a former minister of justice from the SPD, Mrs Däubler-Gmelin.

The third court case at the Federal Court of Labour (BAG) in Erfurt in June 2010 received widespread public attention beforehand. The Solidarity Committee published two letters of support for the cashier, one signed by a number of academics from the social sciences, another signed by a large number of union activists from all continents of the globe. ${ }^{5}$ Well-known commentators in newspapers like Süddeutsche Zeitung commented on the case. Finally, more than two and a half years after she was sacked, the Federal Court of Labour decided that Emmely could go back to her job. The Court did not abolish dismissal by suspicion or the petty-stuff dismissal as general laws. But it emphasised that in the other court decisions the balance between a worklife of thirty-one years with the same contract and a minor theft was not kept. It emphasised that a trust which had been built up over such a long time could not be destroyed that easily. Emmely went back to her job as a cashier again - and German labor law was slightly changed.

This also meant that Emmely was paid the wages for all the time she could not work at Kaiser's; in addition, she could take the holidays that had accumulated. Due to the loss of her job, she had also lost her apartment.

The change in the labour law put in effect with the sentence of the Federal Court of Labour in Emmely's case focused on the application of the petty-stuff dismissal. While its application in the past thirty years assumed that the trust relationship was damaged by any theft, even that of less than one cent, the BAG emphasised that a theft of 1,30 Euro had to be weighed against a life of labour of thirty-one years with the company. The result of this was that 1,30 Euro was not enough to destroy the trust that had accumulated over all this time. But the BAG did not give clear guidelines regarding when this issue of 'trust' is damaged and when not. That modern labour legislation in Germany includes a more or less feudal notion of personal trust - going back to the way work relations were understood in fascist Germany - is a somewhat paradoxical notion given the fact that Emmely's employers changed over time by mergers and by relocation of personnel while she stayed in the same job for thirty-one years and in the same supermarket for fifteen of those years. This personal trust relationship is assumed to be established between her as a person and the company as an organisation, although the latter had changing responsible persons. The dismissal by suspicion was 
not subject to the court sentence and stays fully intact.

\section{Conclusion}

The campaign was successful in its main object: Emmely went back to her job. The campaign was able to channel the anger about the financial crisis and unjust practices of German employers and especially in the retail sector - into public support for Emmely. However, the local trade union branch of Verdi in Berlin was successfully blackmailed by the workers' representatives at Kaiser's. The fact that this was possible underlines the weakness of German unions in the legal construction of German laws on industrial relations (Betriebsverfassungsgesetz). This legal system encourages diverging interests of Works Councils and trade unions, with the former often accumulating more power of negotiation than the latter. In many cases Work Councils tend to defend the interests of their company or their workplace against the interests of the workers (Hälker, 2004; Tietel, 2006).

After the case got widespread public attention, the federal level of Verdi stepped in and supported the campaign in some respects. Different local branches of the retail department of Verdi in the cities of Kassel, Bremen and Erfurt supported the campaign, too.

The solidarity committee was able to lead the campaign with a small amount of funding and no full-time campaigners. Its resources were, first, the political experience of its members, some of them former shop stewards in the automobile industry, others activists from the radical left. Second, Emmely herself was a resource because she was brave enough to take a stand against her employer and her local union branch. She was able to walk into television talk shows on the same day that she lost her court case and talk to newspapers for days. A third resource was Emmely's lawyer, Benedikt Hopmann, who was not afraid to work in the context of a political campaign. While Verdi's lawyer did not want Emmely to make a public issue out of the case at all, her new lawyer Hopmann (who is also working in collaboration with Verdi, but as an independent lawyer) joined Emmely in speaking on a television show (with an outburst of rage about the regulations), and gave interviews to the press in which he addressed the political dimensions of the case.

But the campaign faced important limits: The Federal Court of Labour did not abolish the laws concerning dismissal. This will have effects for further court cases: the lines of interpretation in similar cases changed considerably but there are still no clear criteria about the boundaries of 'trust'. The main intention of the federal court was obviously to calm down the public, which had started to lose trust in the decisions of labour jurisprudence in Germany. But it did so by bringing Emmely back into her job and not by abolishing the two laws on dismissal mentioned above.

Another limit of the campaign was the level of cooperation with the trade union that was accomplished. After the local branch of Verdi withdrew its support, the solidarity committee did not try to contact it again. This was partly due to an overload of work to be done to get the campaign going, since all the activists worked voluntarily in the committee. The federal level of Verdi that supported the campaign later proved to be too inflexible to generate an initiative to support the campaign more systematically. The campaign was also not successful in establishing contacts with employees of Kaiser's in Berlin or elsewhere, except for a tiny group in Berlin that got to know each other during the strike from 2007 to 2009. The solidarity committee lacked the resources to establish more contacts with employees. Employees were careful to voice their opinion about the case and the workers representatives of Kaiser's in Berlin were afraid the campaign for Emmely would harm the economic success of Kaiser's, which could lead to dismissals of workers.

The political structure that enabled the success of the Emmely campaign was based in a small network that emerged around labour conflicts independently from the trade unions in the previous years. Almost everybody in this network all over Germany knows each other due to the small size of the network. Some people in these networks are trade union members and are or were worker representatives in factories; others are independent political activists. These networks of leftist 
unionists also provided for contacts with the retail department of Verdi in cities other than Berlin. In other cases, the solidarity committee later established contacts with other branches of the trade union or shop stewards facing similar problems that Emmely did - and at that time the high level of publicity around Emmely provided for solidarity in these cases. It was also the pragmatic approach of the solidarity committee to cooperate with corporate media like television and right-wing newspapers dominating the media market that helped to enhance public pressure. The German tabloid press giant BILD supported the case of Emmely throughout the campaign, partly because its readers are predominantly composed of the popular classes which voiced overwhelming support for Emmely in a number of surveys conducted.

Verdi, whose member was sacked, did not play a very active role. After Emmely's case got widespread attention, the federal level of Verdi covered the financial costs of further court cases. However, the retail sector of Verdi in Berlin, which stopped its support in the early phase of the campaign, never went back to support her. The responsible union official, Erika Ritter, gave an interview to the mainstream press in summer 2009, after the second court case and the publicity that accompanied it, saying that Emmely was being instrumentalised by radical leftists. Later, though, she celebrated Emmely's victory in the federal court in June 2010. In fact, there was considerable confusion about the position of the trade union. The federal level of Verdi could not afford not to support Emmely after the case got widespread attention in February 2009. The solidarity committee found itself in the awkward situation of working with the federal level of Verdi but not with its local branch (which resides in the same building in Berlin). Furthermore, the federal level of Verdi did not develop original initiatives around the case, but rather reacted to events, lacking the resources or organisational structure to lead the campaign. The solidarity committee did not try to contact the local branch and Mrs Ritter again, thereby deepening the split between these two crucial actors.

An important result is that the trade unions lack the resources and flexibility to help single workers who are sacked after a strike, and that an independent solidarity committee had to fulfil one of the central tasks of the trade union itself: to protect its members from being sacked after or during a strike. It was the trade union that initially called Emmely to strike, but the local trade union did not step in to save her job. This says a lot about why the German trade unions are weak in the retail sector, where the fear of being sacked is widespread among employees. The local branch in Berlin which was open to experiments - like blockading a supermarket, which was a novelty for trade unions - did not know how to deal with the blackmail from their shop stewards other than withdrawing support for an active rank-and-file member.

Another limitation of the campaign was its individualised focus: Although it enabled the general public to rally behind Emmely, because this specfic case seemed to be striking injustice, it disabled a collective stance. The employees of Kaiser's were in general very careful about voicing their opinion because the company was known to be in a difficult situation; in fact, plans to close down all shops of Kaiser's became public during 2014. The small group of about ten workers around Emmely wanted to form a working group but were denied the support of the local trade union branch which was in fear of losing the membership of the Works Council. Given that the number of workers organised in the trade union is quite low in the retail sector, and more so in the Berlin region, this made it easy for the Kaiser's Works Council to blackmail the retail branch of Verdi in Berlin.

\section{Comparison of the Two Campaigns and their Consequences}

\section{Popular anger and media attention}

First, it is interesting that campaigns from the base as well as campaigns led from the union 
leadership can be successful, and both were able to gain the support of a vast majority of the population. In addition, both were able to create a political discourse. Despite all the differences, both campaigns drew their support from a deeply embedded popular anger about experiences in the workplace like overtime, low wages and bad treatment. This popular anger does not always find ways of expression and is below the surface most of the time. In these two cases, it found its way in mass participation in blogs, letters to the editors and so on. For example, after a television show about the Emmely case, there were 400 entries on the website of the TV channel in a few hours, most of them reporting about being bullied at work. These messages, many of them on the Internet, were written by simple people and developed into a conversation of workers on conditions of work. This prompted the media workers to report more about the topics as they realised that media consumers were interested. Both campaigns revealed that symbolic power can be very effective if it is able to mobilise popular sentiment, especially when politicians and legal institutions are concerned about electoral support or the legitimation of institutions like the labour courts. It turned out that labour issues can be successfully debated in the media, something that trade unions had been afraid of doing for some time because of a very strong tradition of union-bashing both in the media and in the population. But the tightening of the labour market, the extension of low-wage jobs and the workfare reforms of the SPD and the Green Party changed the situation: Grievances about repression and payment in labour issues started to be perceived as legitimate anger. Especially during the financial crisis, the media itself was very sensitive to related issues. Working conditions in the retail sector have been a constant object of media attention since 2008, with different employers in focus - Lidl in 2008, Schlecker in 2010 and Amazon in 2012/2013.

The campaign for the minimum wage was embedded in a long-term strategy, while the timeframe and dynamic of the Emmely campaign was centred around the court hearings for the case which took place between July 2008 and June 2010. This was a strength because the focus was clear and the role of the jurisprudence in enabling unjust labour relations came into focus (maybe for the first time in Germany). The judges from the second court case received hundreds of letters from citizens, many of them containing 'criminal content' according to the judges. But the focus on the court sessions was also a weakness because the public attention ended with Emmely's victory in the Federal Court of Labour, despite several ongoing similar cases. The legitimacy of the economic system was in question in Germany just for a very short time after the fall of Lehman Brothers until summer 2009. Emmely's second court case took place at a time when the debate about bonuses of bankers was very vivid, so the campaign could draw on the uneasiness about the global financial crisis to a large extent.

\section{Party politics and trade unions}

The strength of the campaign for the minimum wage lies in its broad approach: the establishment of a legal minimum wage will immediately affect millions of workers in Germany. The campaign was able to establish minimum wages in single sectors, so it could also draw permanent attention from these piecemeal successes. Finally, this piecemeal tactic succeeded in a situation in which the SPD went into a coalition government with the CDU for the second time in the twentyfirst century and was under pressure to prove why such a coalition was useful for the working class. This pressure was enormous, because there is a mathematical majority in Parliament for a coalition of all left-to-centre parties (SPD, Green Party, Left Party). ${ }^{6}$

The lesson that can be learned from the minimum wage campaign is that the trade unions in Germany can lead a proper political campaign and that this is accepted by the public. With this, the trade union established a considerable amount of autonomy with respect to political parties, especially the SPD, which was literally forced to take up a demand that originated in the Left Party. The Left Party was able to bring its own demand to the centre of politics, but it was also weakened 
in the long term because it was not able to gain from the dynamic of the minimum wage campaign. It was unable to find a new topic that was original to the party, other than demanding a higher minimum wage of 10 Euro an hour instead of 8,50 Euro. But the openness of Mr Bsirske, the head of Verdi, and later of the entire union federation, towards a demand made public by the Left Party was a clever move to encourage a shift of the SPD's position. The fact that after the workfare reforms of the SPD the Left Party emerged as a second social democratic party on the national level enabled the trade unions to gain influence by using party competition. The trade union leaders adapted to the new situation very quickly and used the opportunity, although most of its top officials are members of the SPD. Mr Bsirske is a member of the Green Party, which allows him a bit more space for manoeuvre within the power structures of the trade union federation.

The trade unions in Germany have defined themselves primarily as actors within the field of labour relations, and this changed to some extent with the minimum wage campaign. The campaign also strengthened the umbrella trade union organisation, the DGB, which was for a long time perceived as an extension of the single trade unions of which it was composed, most of all the three big ones - IG BCE (mining, chemicals, energy), IG Metall (metal workers) and Verdi (services). The minimum wage campaign enabled the DGB as an umbrella to set its own agenda and gain some independence from its member unions whose weight consists in the number of members that constitute the financial and political basis of the DGB.

\section{Legal issues}

One lesson that can be learned from the Emmely campaign is that 'weak' actors with almost no financial resources can yield big results if they mobilise popular anger about workplace relations and workers' treatment by labour courts. Many people immediately identified themselves with Emmely, and the expression Klassenjustiz (class-biased jurisprudence) was suddenly debated in all major newspapers - a term that was only used by Marxist-Leninist microparties in Germany until 2009. Second, the campaign showed that the legal system is not independent but exhibits very precise reactions regarding public debate. As soon as it seemed to be possible that the general public would question the legitimacy of labour jurisprudence in Germany, the Federal Labour Court changed the line that had prevailed for thirty years. The change was not abrupt, however, but a very gradual one. It allowed Emmely to return to her job, but did not do away with the feudal remnants in German labour legislation.

At the same time, however, the trade unions in Germany got used to the two kinds of dismissal that were exemplified in the Emmely case. This entailed non-sufficient protection for many workers from arbitrary punishment, including by shop stewards who are the backbone of union representation in workplaces in Germany. Although the topic relates to key foundations of the work of the trade unions, they were not very keen to tackle the issue when the Emmely campaign gained speed - and they also did not stick to the issue after Emmely got back her job.

\section{Lessons}

There are three levels on which the trade unions could do better in this area.

- The trade unions in Germany do often not confront areas which have been settled by labour law. But labour law in Germany is to some extent established by judges and courts, and not by legislation. This means that labour regulations can also be changed by judges and courts. Campaigns to change certain regulations can be efficient if they are led with a specific case. A lesson to be drawn from this is that German trade unions could do better in engaging more in labour law reform. After the scandals about certains forms of legal dismissal of workers, the issue was dropped again by the trade unions. Another problem is the German 
system of industrial relations that hands over power resources to Works Councils at the expense of trade unions. This was already a problem in the metal workers strike in East Germany in 2003 when West German worker representatives called for a boycott of the strike. The law that lays the groundwork for the German labour system, the Betriebsverfassungsgesetr, is a source of identification fot the trade unions as a whole, and to demand changes in its structure is an effective taboo. But given that a legal minimum wage was a taboo for most German trade unions in the past years, the changing environment in work relations might enable other changes, too.

- The trade unions in Germany often do not protect single workers who are their members, either because of bad routine (see first point) or because they lack the resources. This became an object of public debate in the aftermath of the Emmely case when similar cases went public. This diminishes trust of workers towards the trade unions.

- The trade unions in Germany are sometimes not flexible enough to step into political campaigns because they focus on their personal resources for their 'core business'. To focus on the core business is of course essential, but might put the trade unions into a deadlock (see second point).

Both campaigns addressed inequality in German labour relations. The minimum wage campaign effectively established a legal threshold that will diminish a fizzling out of the bottom of the wage spectrum and therefore decrease the overall inequality, at least to some extent. The Emmely campaign tried to challenge inequality in labour relations: the labour contract as a legal basis for employment seems to be a contract among equals but labour law and jurisprudence - and the property relations in the background - enable employers to terminate the labour contract either by suspicion or because of marginal reasons. The notion of 'trust' is especially unequal: The trust of workers might be exhausted on a number of occasions, which does not provide them with special rights. But the lack of trust on the side of employers does provide them the opportunity to terminate the contract.

However, against the background of a general rise of inequality in Germany, these campaigns could only ameliorate some of the effects of this larger trend.

\section{NOTES}

${ }^{1}$ The PDS emerged out of the former Sozialistische Einheitspartei Deutschlands (SED), which led all governments in the German Democratic Republic between 1946 and 1990. The SED renamed itself SED-PDS in December 1989, and changed its name to PDS in February 1990.

${ }^{2}$ See http://www.vsp-vernetzt.de/soz-0610/061010.htm, accessed 2 February 2015.

${ }^{3}$ See https://www.mindestlohn.de/kampagne/aktion/2008/cdu-parteitag-in-stuttgart/, accessed 2 February 2015.

${ }^{4}$ See https://www.mindestlohn.de/kampagne/aktion/2008/cdu-parteitag-in-stuttgart/, accessed 2 February 2015.

${ }^{5}$ See http://archiv.labournet.de/branchen/dienstleistung/eh/emmely interlektuelle 08062010.pdf; and http://archiv.labournet.de/branchen/dienstleistung/eh/interationale-soli presse03062010.pdf, accessed 2 February 2015.

${ }^{6}$ The number of seats of the three left parties combined would result in an absolute majority in the 
first house of Parliament, which is seen as a necessary condition to form a government in Germany. It is normal to govern in party coalitions, but since 1949 they have always been comprised of no more than two parties. In addition, the SPD refuses to enter into a government coalition with the Left Party for political reasons. This has resulted in a series of 'grand coalitions' formed by the two big parties - the CDU and the SPD.

\section{REFERENCES}

Amlinger, M., Bispinck, R. and Schulten, T. (2014) Niedriglohnsektor: Jeder Dritte ohne Mindestlohn? Ausnahmen vom geplanten Mindestlohn und ihre Konsequenzen. WSI Report January 2014. Available online at http://www.boeckler.de/pdf/p wsi report 12 2014.pdf; accessed 19 February 2014.

Arps, J. (2008) Verbotener Arbeitskampf. Tageszeitung, June 25.

Bispinck, R. and WSI-Tarifarchiv (2014) Tarifliche Vergütungsgruppen im Niedriglohnbereich 2013. Eine Untersuchung in 41 Wirtschaftszweigen. In Elemente qualitativer Tarifpolitik, Nr. 77, Januar 2014. Available online at http://www.boeckler.de/pdf/p ta elemente 77 2014.pdf; accessed 19 February 2014.

Die Welt (2014) Jobcenter siegt im Streit über Lohndumping. November 10. Available online at http://www.welt.de/wirtschaft/article134194204/Jobcenter-siegt-im-Streit-ueber-

Lohndumping.html; accessed 2 February 2015.

Der Spiegel (2014a) Beschluss im Bundestag: Deutschland bekommt den Mindestlohn. July 3. Available online at http://www.spiegel.de/politik/deutschland/mindestlohn-bundestagbeschliesst-lohnuntergrenze-a-978934.html; accessed 4 July 2014.

Der Spiegel (2014b) Mindestlohn beschert dem Staat zusätzliche Milliarden.. July 4. Available online at http://www.spiegel.de/wirtschaft/soziales/mindestlohn-forscher-rechnen-mit-entlastung-fueroeffentliche-haushalte-a-979132.html; accessed 4 July 2014.

Frankfurter Allgemeine Zeitung (FAZ) (2014) Bundestag beschließt Mindestlohn von 8,50 Euro. July 4.

Hälker, J. (2004) Betriebsräte in Rollenkonflikten. Betriebspolitisches Denken zwischen Co-Management und Gegenmacht. München: Rainer Hampp.

Handelsblatt (2013) Manager plädieren für Mindestlohn', July 14. Available online at http://www.handelsblatt.com/politik/deutschland/klare-mehrheit-dafuer-manager-plaedierenfuer-mindestlohn/8495300.html; accessed 2 February 2014.

Linksfraktion (2013) Auf dem Weg zu einem flächendeckenden gesetzlichen Mindestlohn. Available online at http://www.linksfraktion.de/nachrichten/weg-flaechendeckenden-gesetzlichenmindestlohn; accessed 2 February 2015.

Schulten, T. and Bispinck, R. (2014) Stellungnahme des Wirtschafts- und Sozialwissenschaftlichen Institutes (WSI) in der Hans-Böckler-Stiftung zum Gesetzentwurf der Bundesregierung über ein ,Gesetz zur Stärkung der Tarifautonomie، (Tarifautonomiestärkungsgesetz) vom 28 Mai 2014, BT-Drs. 18/1558'. Available online at http://www.boeckler.de/pdf/pm wsi 201406 30.pdfm; accessed 4 July 2014.

Simantke, E. (2010) Ein aufgeladener Akku ist kein Kündigungsgrund. Tagesspiegel, September 2. Available online at http://www.tagesspiegel.de/wirtschaft/stromklau-ein-aufgeladener-akku- 
ist-kein-kuendigungsgrund/1917448.html; accessed 2 February 2014.

Tietel, E. (2006) Konfrontation - Kooperation - Solidarität. Betriebsräte in der sozialen und emotionalen Zwickmüble. Berlin: Edition Sigma.

Verdi (2014) Kundgebung für einen Mindestlohn ohne Ausnahmen. Available online at https://www.verdi.de/themen/nachrichten/++co++99b21208-ffaa-11e3-a748-52540059119e; accessed 4 July 2014.

WAZ (2009) 2,85 Euro. March 27. Available online at http://www.derwesten.de/staedte/ gelsenkirchen/2-85-euro-id552946.html; accessed 2 February 2014.

Weinkopf, C. and Bosch, G. (2013) Gut gemachte Mindestlöhne schaden der Beschäftigung nicht. IAQ Report 4/2013. Available online at: http://www.iaq.uni-due.de/iaqreport/2013/report2013-04.pdf; accessed 3 September 2015.

\section{BIOGRAPHICAL NOTE}

JÖRG NOWAK holds a PhD in Political Sciences and is working on a research project on mass strikes in India and Brazil. He currently works in a German NGO as a researcher on inequality. His research areas are state theory, strike movements, industrialisation of the Amazon areas in Brazil, and the philosophy of Louis Althusser. [Email: joerg.nowak@gmx.de] 